\title{
ZNANJE NI BILO ŠE NIKOLI TOLIKO VREDNO KOT DANES!
}

Nikoli v zgodovini kapitalizma niso izobraževanju in usposabljanju zaposlenih pripisovali tako velikega in širokega pomena kot v tem trenutku, ko se globalno gospodarstvo spopada morda z najhujšo svetovno gospodarsko krizo doslej. Kadarkoli in kjerkoli je kapitalizmu uspelo narediti velike korake v izboljšanju človeške produktivnosti, se je to zgodilo s primitivno akumulacijo premoženja bogatim, z uničujočim izkoriščanjem delavcev, revolucionarnimi tehnološkimi spremembami, spremembami dotedanjih vzorcev in metod dela ali z akumulacijami surovin, ki so kasneje postale strateško pomembne. Redko, če sploh kdaj, je izobraževanje in znanje pomenilo osrednji steber ekonomske rasti.

Zdaj, po koncu kapitalizma dvajsetega stoletja in v času tektonskih gospodarskih premikov na svetovni ravni, se med politiki različnih prepričanj pojavlja nov konsenz. Teтu konsenzu pritrjujejo tudi znanstveniki in popularno splošno mnenje, in sicer, da je odličnost nacionalnega izobraževalnega sistema neke države postala ključna pot do konkurenčnih prednosti in superiornosti v prihodnosti.

Splošno mnenje je, da imajo uspešne in učinkovite izobraževalne sisteme predvsem $v$ razvitih državah, kjer ima $v$ splošnem izobrazba tudi v javnosti večjo veljavo in ugled. $V$ industrializiranih državah velja, da je ključ do povečanja produktivnosti dela prav sistem znanja in vešcin, ki je vzpostavljen tako, da na dolgi rok čim bolj ustreza potrebam gospodarstva in celotne družbe, ki je tako uspešnejša, iz česar posledično ugotavljajo, da ima dobro načrtovan in
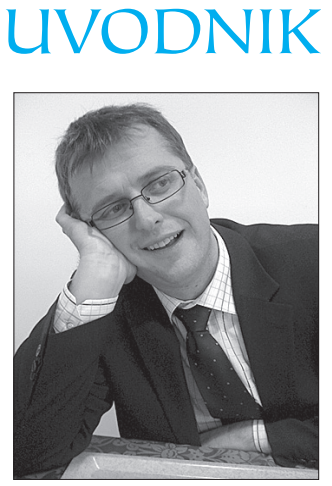

učinkovit sistem izobraževanja in usposabljanja velik dolgoročen vpliv na blaginjo posamezni$k a$ in naroda kot celote. Načrtovalci politike in njenih izvedbenih ukrepov vsaj deklarativno vlagajo velike napore $v$ zagotavljanje čim boljših izobraževalnih inštitucij. Pri tem izhajajo iz domačih političnih ideologij, vendar se radi ozirajo tudi čez meje in poskušajo ugotoviti, česa se lahko naučijo od konkurenčnih narodov, si tam sposodijo politike in strategije ter seveda dobijo možnost primerjave. Vendar je sosedova trava pogosto videti bolj zelena, kot je v resnici, in včasih si načrtovalci dejansko izposodijo tudi ideje izobraževalnih politik, ki $v$ drugi državi pravzaprav ne delujejo preveč uspešno.

Najbrž je glavni razlog, da je izobraževanje in usposabljanje tako pogosta točka na dnevnih redih razvojnih razprav v mnogih državah, prav $v$ dejstvu, da obstaja splošno prepričanje o pozitivnih povezavah med kakovostjo izobraževanja in življenjskim standardom v neki državi. Čeprav to drži, pa je vpliv solidne izobrazbe še veliko širši od tega, da posameznik z dobro izobrazbo najde dobro in ustrezno nagrajeno zaposlitev. Izobrazba za izpolnjevanje obveznosti vsakega državljana in izobraževanje za osebno izpopolnitev posameznika sta vedno bili in morata ostati osrednji točki izobraževalnega sistema.

Zdi se, da je splošno veljavno prepričanje, da je več izobraževanja in usposabljanja $v$ vsakem primeru dobro za moderno gospodarstvo, in da je edino vprašanje, kako povečati učinkovitost izobraževalnih sistemov. Vendar je tako prepričanje teoretično in empirično slabo 
podkrepljeno in hkrati brez strokovnega konsenza o tem, kakšna je prava mera glede količine in vsebine izobraževalnih vsebin, ki so na voljo, da jih prebivalstvo konzumira. Značilno je stališče, da naj bi izobraževanje in usposabljanje predvsem izboljšalo produktivnost delavcev, vendar mnoge sociološke študije kažejo, da imajo iste izobraževalne vsebine na nekatere delavce drugačen vpliv kot na druge. Zato tudi ni presenetljivo, da je povpraševanje po izobraževalnih storitvah med delodajalci za njihove delavce pravzaprav majhno. Delodajalci se namreč zavedajo, da nekako kupujejo mačka $v \check{z} a k l j u$, saj ni znanja, s katerim bi neki sistem izobraževalnih vsebin lahko postavili tako, da bi univerzalno izpolnjeval pričakovanja vseh delodajalcev. Tudi stroka, torej ponudniki izobraževalnih storitev, se ne znajdejo in kaj prida več od kazanja s prstom na delodajalce, da ne razumejo pomena izobraževanja, niso sposobni ponuditi kot protiargument.

Po drugi strani je kljub mnogim raziskovalnim naporom še vedno slabo ovrednotena povezava med količino in kakovostjo izobraževanja in ekonomskimi rezultati, tako na ravni posameznika kot podjetja in družbe kot celote. Če denimo trdimo, da bolj usposobljeni delavci povečujejo dobičkonosnost podjetja, je to bolj vera $v$ anekdote kot $z$ empiričnimi dokazi podkrepljena ugotovitev. Longitudinalnih študij, ki bi v daljšem obdobju proučevale vzorec podjetij in spremljale povezave med ravnjo izobrazbe in usposobljenosti zaposlenih ter gibanjem dobič$k a$, enostavno ni. Industrializirane države pogosto argumentirajo svojo gospodarsko rast $z$ izboljšavami univerzitetnega študija, vendar tudi za to ni pravih empiričnih dokazov. Prav tako ni dokazov, da delodajalci zahtevajo vse bolj usposobljeno delovno silo, kar najbrž izhaja predvsem iz zmešnjave, kaj pravzaprav pomeni termin »usposobljen«.

O umestitvi gospodarstva oziroma podjetniškega sektorja v trajni družbeni razvoj države ali regije najbrž nima smisla posebej razpravljati. Smisel dobro delujočega gospodarstva je v hitri menjavi proizvedenih dobrin za denar, ustvarjanju dodane vrednosti pri teh menjavah in novem in novem poganjanju tega kroga dobrin in denarja. Država ima pri tem ciklusu ključno nalogo $v$ zagotavljanju čim bolj spodbudnega okolja, ki se začne pri stabilnem političnem sistemu in nadaljuje z urejenim pravnim, monetarnim, fiskalnim, socialnim, šolskim sistemom, in omogoča igralcem na trgu čim bolj intenzivne gospodarske aktivnosti.

Če je bilo dolga desetletja mogoče ekonomske odnose večinoma razumeti skozi vzpostavljanje ekonomskih ravnotežij tam, kjer se srečujeta povpraševanje in ponudba, se je v prvi polovici prejšnjega stoletja začel v ekonomski misli in znanosti pojavljati arhetip podjetnika kot človeka, ki bodisi vzpostavlja ali ruši ekonomska ravnotežja. Israel Kirzner je videl podjetnika kot špekulanta, ki kupi nekaj tam, kjer je ceneje, in gre to prodat tja, kjer lahko iztrži višjo ceno, in tako zasluži s tem, da ima na voljo boljše informacije kot kupec. S tem tudi vzpostavlja ekonomsko ravnotežje, tako da kupuje tam, kjer so presežki, in prodaja tja, kjer neke dobrine primanjkuje. Potrditev omenjene teorije lahko najdemo s spremljanjem vsakodnevnih gospodarskih dogajanj. Evropska podjetja ne morejo več konkurirati v panogah z nizko dodano vrednostjo, kjer je mogoče preživeti samo z nizkimi stroški dela, kar uspeva tam, kjer so ljudje zadovoljni z minimalnimi plačami, to pa $v$ Evropi vsekakor ni mogoče. In prav v zgodbi o dodani vrednosti se skriva odgovor na vprašanje, kam naj se Evropa in z njo tudi Slovenija usmeri, da bi družno odgovorila na težave, ki jih prinašajo globalni gospodarski tokovi, in našla dolgoročen in trajen izhod iz aktualne gospodarske krize.

Že Joseph Schumpeter je trdil, da je podjetništvo pravzaprav inovacija in podjetnik inovator. Podjetništvo ni samo razvoj, proizvodnja, orga- 
nizacija, trženje, finance, ampak so predvsem spremembe, ki jih podjetniki ustvarijo ali samo opazijo in izkoristijo sebi v prid. Kanadski profesor Filion pa pravi, da je razlikovanje med podjetništvom in menedžmentom umetna dilema. Podjetnikom je treba pomagati, da razvijejo ustvarjalnost, pridobijo menedžerska znanja in vodstvene sposobnosti. Hkrati bi se glede prihodnosti sodobnih menedžerjev lahko strinjali $z$ ameriškim raziskovalcem Georgeom Zoghlinom, ki pravi, da je današnji menedžment pred dilemo: ostati v udobnih menedžerskih stolčkih in podjetno voditi podjetje za lastnike ali pa se preleviti v podjetnika lastnika in nič več mirno spati. Posledica razjasnitev omenjenih definicij je bil nastanek nove paradigme podjetniškega in menedžerskega usposabljanja in izobraževanja: menedžerje je treba učiti podjetništva in podjetnike učiti menedžmenta.

Vrnimo se nazaj k vprašanju dodane vrednosti. Podatki o tehnološki razvitosti in strukturi znanja za Slovenijo in Nemčijo izpred nekaj let kažejo, da slovenski izdelki dosegajo v povprečju 5. do 6. stopnjo, nemški pa kar 11. stopnjo na 15-stopenjski lestvici razvojno tehnološke intenzivnosti. Seveda je bolj kompleksne izdelke v splošnem mogoče dražje prodajati, torej je stopnja dodane vrednosti v poprečju višja, hkrati pa je treba za tak poslovni model zagotoviti bolj izobražen in bolje usposobljen kader. Tako za doseganje omenjene stopnje kompleksnosti potrebujemo $v$ Sloveniji v povprečju 4. stopnjo izobrazbe (kvalificirani delavci), $v$ Nemčiji pa je to povprečje kar za dve stopnji višje, saj je za njihovo stopnjo razvoja potrebna izobrazba visoke strokovne šole. Če torej Slovenci konkurenčnih prednosti svoje države oziroma gospodarstva ne želimo graditi na nizkih stroških dela in poceni delovni sili, se moramo usmeriti k proizvodnji bolj kompleksnih proizvodov in storitev $z$ višjimi stopnjami dodane vrednosti, kar pa bodo sposobni početi le bolje izobraženi in usposobljeni ljudje. Irska, eden od svetovnih gospodarskih čudežev, je naredila preobrat iz gospodarstva, ki je temeljilo na tradicionalnih panogah, $v$ eno najbolj visokotehnološko usmerjenih gospodarstev, kjer opravijo ogromno razvojnega dela in veliko proizvodnje $z$ visoko dodano vrednostjo. Vendar proučevanje tega dela irske zgodovine hitro pokaže, da o čudežu ni primerno govoriti. Med preostalimi dosežki širšega družbenega razvoja je Irski $v$ letih 1975 do 1990 formalno raven izobrazbe svojega prebivalstva uspelo zvišati v povprečju skoraj za dve stopnji. Rezultati v gospodarstvu in na drugih področjih so se kmalu pokazali. Tudi iz Finske, druge evropske zgodbe o uspehu, prihajajo zanimivi podatki. Nokia, svetovni gigant na področju elektronike, največji proizvajalec mobilnih telefonov in tisti, ki je še vedno za korak pred konkurenco z vidika novih in seveda naprednejših tehnologij, ki jih pošiljajo na trg, se iz vloge proizvajalca gumijastih škornjev na položaj, ki ga ima zdaj, ni zavihtela zato, ker so bile zvezde ugodno razporejene, ali pa, ker so pihali pravi vetrovi. Pri razvoju enega samega modela novega telefona ponavadi hkrati dela nekaj tisoč ljudi, od katerih jih le nekaj odstotkov nima univerzitetne izobrazbe. Gre za usmerjen proces, $v$ katerega so vključeni tudi mnogi nacionalni potenciali najvišjega ranga. Na znanju temelječa družba torej ni zgolj fraza, ki se dobro sliši in se z njo moramo strinjati, ampak je potencialne rezultate te družbe z razmeroma veliko verjetnostjo mogoče napovedati kot boljšse od rezultatov družbe, ki znanju $v$ svojih strateških usmeritvah ne namenja bistvene pozornosti.

Ni dovolj, da se pomena izobraževanja zavedajo tisti, ki načrtujejo izobraževalno politiko, ampak je treba usmeriti napore v promocijo znanja kot vrednote in orožja v boju za boljše življenje in družbeno blaginjo. Pridobivanje novega znanja in njegovo posodabljanje naj postane življenjski moto posameznika, ki se v določenem okolju zaveda odgovornosti zase kot posameznika in kot državljana. Odzvati se bo moral tudi izobraževalni sistem in hitreje 
odgovarjati na potrebe, pri čemer ne zagovarjamo teze, da mora biti ponudba izobraževanja samo tržno pogojena in se kratkoročno ponujajo predvsem tisti programi, po katerih je največje povpraševanje oziroma ki imajo najboljše obete za dobro zaposlitev. Zato ponudba izobraževanja najbrž ne more biti samo tržna kategorija, ampak tudi odraz vizije gospodarskega in širšega družbenega razvoja Slovenije $v$ evropskem in globalnem kontekstu.

Za razvoj izobraževalnih programov v kontekstu ekonomske rasti in $v$ danem trenutku predvsem za izhod iz globalne recesije bo potrebnega več znanja in razumevanja prav na področju povezovanja in odvisnosti ekonomske rasti, družbene blaginje in trajnostnega razvoja od ustreznega izobraževalnega sistema. Prav tako je treba izrazito zahodnjaško razmišljanje $v$ takih raziskavah kombinirati tudi z izsledki iz drugih kultur. Na mnogih področjih se je namreč pokazalo, da se japonski kapitalizem vendarle razlikuje od evropskega ali ameriškega.

Doc. dr. Jaka Vadnjal

GEA College - Visoka šola za podjetništvo

$$
\text { dreaturial }
$$

